\title{
Horizontal Drilling of Crude Oil: A Challenge to the Norms of Property Rights
}

\author{
Kato Gogo Kingston ${ }^{1} \&$ Charity Olunma Kaniye-Ebeku ${ }^{2}$ \\ ${ }^{1}$ Faculty of Law, Rivers State University, Port Harcourt, Nigeria \\ ${ }^{2}$ Faculty of Law, University of Port Harcourt, Choba, Port Harcourt, Rivers State, Nigeria \\ Correspondence: Dr. Kato Gogo Kingston, Faculty of Law, Rivers State University, P.M.B 5080, \\ Nkpolu-Oroworukwo, Port Harcourt, Rivers State, Nigeria. Tel: 234-80-3768-4266. E-mail: \\ gkingstonlaw@gmail.com
}

Received: July 6, 2017

Accepted: August 5, $2017 \quad$ Online Published: September 12, 2017

doi:10.5539/ilr.v6n1p138

URL: https://doi.org/10.5539/ilr.v6n1p138

\begin{abstract}
Two altitudinal relationships propel current crude oil exploration jurisprudence and litigation namely: Surface land ownership and sub-surface rights (including mineral ownership). In the United States, the conflicts between the surface and mineral owners has theatrically increased in the last decade. Elsewhere, notably Nigeria, conflicts over land rights and the ownership of sub-surface minerals is yet to be fully resolved. Our goal herein is to explore the interaction between the law of property and the tort of trespass as applicable to the surface and subsurface exploration and extraction of crude oil and natural gas with specific focus on the scientific advances in horizontal drilling techniques widely used by the oil corporations in the various oil reservoirs across the world. Horizontal drilling ${ }^{1}$ is described in this paper, as the exercise of drilling for liquid and gaseous mineral resources by other means other than sinking vertical wells. We argue that, horizontal drilling is one of the easiest means by which governments could lawfully capture ${ }^{2}$ crude oil and gas from reservoirs of neighbouring nations to the extent that joint development agreement becomes unnecessary. Also, we opined that nations such as Nigeria could easily resolve issues of resources allocation by reducing the spread of surface wells. This could be achieved through the establishment of very few centralised drilling sites where slant or horizontal drilling can tap into various reservoirs thereby, eliminating the contestation of local agitators.
\end{abstract}

Keywords: drilling, crude oil, property rights, trespass, Nigeria

\section{Introduction}

The history of crude oil drilling is often traced to the era of vertical drilling well, that was the singular method of retrieving and mining the much-treasured liquid minerals, including crude oil, natural gas and water straight from underneath the surface of the earth. The discovery and modern development of horizontal drilling expertise have made it conceivable to reach difficult terrain and once impossible locations below the earth. However, horizontal drilling starts with vertical interception than a right-angle tilt for horizontal drilling to succeed. It is important to note that, horizontal drilling may be used unethically to 'steal', trespass and convert the property of others as the operation occurs underneath the surface of the earth.

Horizontal or directional drilling as a technique of extracting crude oil and natural gas has evolved for about two centuries. The technique has been achieved and is being sustained through consistent modernisation and human tenacity. It is, arguably, the most improved and socially efficient tool of the oil industry with regards to field operations and cost efficiency. Crude oil industrialists are consistently seeking ways of reducing costs and enhancing profit margin, hence the quest for new models of extracting, transporting, refining, and using crude oil and gas are at the forefront of the transnational investment planners' agenda.

\section{The Dilemma of Private Ownership of Mineral Lands}

The starting point of this discourse is to explore the evolving concept of land rights and the extent to which land owners can exercise their ownership rights with regards to crude oil extraction. Several legal observers,

\footnotetext{
${ }^{1}$ In this paper, term horizontal drilling is used interchangeably with directional drilling and slant drilling.

${ }^{2}$ As illustrated in Coastal Oil \& Gas Corp. v. Garza Energy Trust 268 S.W.3d 1, 15 (Tex. 2008).
} 
including Rose, ${ }^{3}$ and Pierce, ${ }^{4}$ opined that, property rights are not static in nature, hence, subject to changes. Particularly, Rose argues that, "the contours of ownership become further defined as issues arise and are resolved. Until circumstances cause parties to focus on an ownership issue, there is no need to expend resources to further define ownership in the new context. For example, as techniques are developed to detect and accurately measure frac fissures [in oil and gas production, land] disputes are more likely to arise." ${ }^{5}$ This ownership of land is at the forefront of many crude oil crises across the world especially in the developing countries. There is, thus, a rising call for the definition and concept of land ownership to include the surface and sub-surface minerals. For example, in Duggan v. Davey, ${ }^{6}$ the court held that: "the ownership and possession of the soil extended to the centre of the earth, and usque ad coelum, and included everything upon its surface and within its bosom." " Also, in Fisher v. Continental Resources, Inc. ${ }^{8}$ the court said: “... property rights extend to the sky and to the depths." In view of these two ancient cases, the common law doctrine of trespass to property was made easy to prove in accordance to the ad coelum maxim which demarcated between one's property and the property of others. Although, where a "trespass may be committed on, beneath, or above the surface of the earth. However, it was not easy to establish trespass where it occurs underneath the earth surface, except by the use of similar technology as those of the trespassers. This was the situation in the case of Coastal Oil \& Gas Corp. v. Garza Energy Trust, ${ }^{9}$ where it was held that, there was no "actionable" trespass when horizontal drill shaft stretched into adjacent lands. On the contrary, in Mission Res., Inc. v. Garza Energy Trust, ${ }^{10}$ the court held that, there was a trespass to property which stemmed from drill shaft, hence damages were awarded in favour of the plaintiff.

In 1859, the very first known and documented commercial oil well was drilled in the Pennsylvania town of Titusville, United States. ${ }^{11}$ It is crucial to note that, before the discovery of underground crude oil reserves, the doctrine of cujus est solum ejus est usque ad coelum et ad inferos was widely approved by many nations. However, the discovery and use of crude oil alters the full implication and the enforceability of the ad coelum principles. This so because, the judiciary found that the transient nature of crude oil and gas made stringent enforcement of the ad coelum principles very unfeasible. Also, the courts are of the view that, crude oil extraction is necessary for human and material development hence, if the ad coelum principles are applied extensively, industrialisation would have blocked. It is common legal knowledge that the maxim of ad coelum ${ }^{12}$ is no longer practicable in contemporary property law. The old maxim was illustrated in the case of Gray-Mellon Oil Co. v. Fairchild, ${ }^{13}$ where the court stated that:

"Oil and gas in the earth stands much as water percolating under the earth. The owner in fee owns to the center of the earth. But he does not own a specific cubic foot of water, oil, or gas under the earth until he reduces it to possession ... While the oil is fugitive, the sand bearing oil is as stationary as a bank of coal. The only practical use to which the oil-bearing sand can be put is to get the oil out of it. The exclusive, permanent right to get the oil from the sand is necessarily a right to a part of the land, for to use the sand in any other way would be to destroy the right to extract the oil from it, as the sand must be allowed to remain as it is for the oil to flow through it" ${ }^{\text {"14 }}$

From Gray-Mellon Oil Co and subsequent court decisions, it became clear that, for the avoidance of doubt, in

\footnotetext{
${ }^{3}$ See Rose, Carol M. (1996) A Dozen Propositions on Private Property, Public Rights, and the New Takings Legislation, 53 WASH. \& LEE L. REV. 265, 269

${ }^{4}$ David E. Pierce (2011) Carol Rose Comes to the Oil Patch: Modern Property Analysis Applied to Modern Reservoir Problems, 19 PENN ST. ENVTL. L. REV. 241, 242-43

${ }^{5}$ Rose, ibid.

${ }^{6} 26$ N.W. 887 (Dakota 1886), cert. dismissed, 131 U.S. 433 (1889).

${ }^{7}$ Ibid. p. 890 .

${ }^{8}$ No. 1:13-cv-097, 2014 WL 4410206, at 11 n.3 (D.N.D. Sept. 8, 2014).

${ }^{9} 268$ S.W.3d 1 (Tex. 2008).

${ }^{10} 166$ S.W.3d 301, 309 (Tex. Ct. App. 2005)

${ }^{11}$ Lowe, John S. (1988) Oil And Gas Law 8 (2d ed.)

${ }^{12}$ The ancient maxim of Ad coelum (Latin expression: Cuius est solum, eius est usque ad coelum et ad inferos) which states that, the owner of a piece of land owns everything on the surface, below the surface to the cote of the earth and above the surface of the land, even up to the sky. It also implies, that the land owner is the owner of everything in and under it including all the minerals such as coal, but not the migrating liquid minerals such as oil and gas which are capable of being captured.

${ }^{13} 292$ S.W. 743 (Ky. Ct. App. 1927)

${ }^{14} \mathrm{Ibid}$, at at 745
} 
countries such as the United States where private ownership of mineral rich lands is authorised by law, mineral estates can be legally detached from the surface estate. ${ }^{15}$ Hence, in Mound City Brick \& Gas Co. v. Goodspeed Gas \& Oil Co., ${ }^{16}$ it was held that, despite oil and gas being an integral part of the land, "the stratum in which they are found is capable of severance, and by an appropriate writing the owner of the land may transfer the stratum containing oil and gas to another. Such party acquired an estate in and title to the stratum of oil and gas, and thereafter it becomes the subject of taxation, encumbrance, or conveyance." ${ }^{17}$ On whether, a lessee can acquire the ownership of the privately-owned minerals, the court emphatically ruled in the lessee right to conversion. This was illustrated in Emeny v. United States ${ }^{18}$ where it was held as follows:

"The surface of the leased lands and everything in such lands, except the oil and gas deposits covered by the leases, were still the property of the respective landowners ... This included the geological structures beneath the surface, including any such structure that might be suitable for the underground storage of 'foreign' or 'extraneous' gas produced elsewhere.","

It is axiomatic in common law that the owner of land can convey his proprietary rights and interests in oil and gas beneath the surface without conceding his title to the surface. However, there is the possible fact of a separation between the ownership of the surface and the ownership of oil and gas beneath that surface, emanating from the terms of the leasehold agreement. Apart from the United States and Canada, which has distinctive and wide-ranging private and state ownership rules pertaining to land and minerals, many countries in the world, vests in the government, the title to all valuable mineral reservoirs, including deposits located beneath what should be privately owned lands. ${ }^{20}$

"Virtually all mineral ownership regimes are based on the jurisprudential theory of state sovereignty. The sovereign of a defined geographical area has an exclusive legal domain over the area, including its natural resources...the most common global regimes places ownership of resources in the government ...Energy resources are subject to government ownership in virtually all the countries except for North America ... Private ownership of natural resources is possible only in the United States of America, Canada and perhaps a few other countries. Even in the United States and Canada, the bulk of the mineral reserves are owned by the government." 21

The system of land rights approved by the laws of certain countries are reminiscent of lease land holding for example, in Nigeria, the current governing land law. ${ }^{22}$ In essence, every private land holder in Nigeria holds such lands for term of years to be determined by the government through various the territorial trustees. ${ }^{23}$ With regards to the rights of the individual land holder and mineral rights, the Land Use Act essentially places the ownership rights in the federal government. This outright federal ownership of crude oil and other minerals, is empowered by section 44(3) of the Constitution of the Federal Republic of Nigeria inter alia:

"... the entire property in and control of all minerals, mineral oils and natural gas in

\footnotetext{
${ }^{15}$ See: Jilek v. Chicago, Wilmington \& Franklin Coal Co 47 N.E.2d 96 (Ill. 1943)

${ }^{16} 109$ p. 1002, 1004 (Kan. 1910)

${ }^{17}$ Bruce M. Kramer (2014) Horizontal Drilling and Trespass: A Challenge to the Norms of Property and Tort Law. Colombia Natural Resources, Energy \& Environmental Law Review Vol. 25:2 p. 295

${ }^{18} 412$ F.2d 1319 (Ct. Cl. 1969).

${ }^{19}$ Bruce M. Kramer, ibid, at 297

${ }^{20}$ Kingston, Kato Gogo (2014). (Unpublished) Pollution and Environmental Responsibility In Petroleum Extraction In The Niger Delta Of Nigeria: Modelling The Coase Theorem. $\mathrm{PhD}$ (Law) thesis submitted to the University of East London, England, United Kingdom, p. 63

${ }^{21}$ Smith, E. Ernest, (2013) World Energy Resources: Ownership, Control and Development in Smith et. al., (eds) International Transactions $2^{\text {nd }}$ Edition. Cited in Douglas T. Mailula Protection of Petroleum Resources in Africa: A Comparative Analysis of Oil and Gas Laws of Selected African States, A PhD thesis submitted to the University of South Africa, p. 45

${ }^{22}$ The Land Use Act 1978, is the current governing law that controls lands in Nigeria. The preamble states inter alia: “An Act to Vest all Land compromised in the territory of each State (except land vested in the Federal government or its agencies) solely in the Governor of the State, who would hold such Land in trust for the people and would henceforth be responsible for allocation of land in all urban areas to individuals resident in the State and to organisations for residential, agriculture, commercial and other purposes while similar powers will with respect to non-urban areas are conferred on Local Governments.(27 $7^{\text {th }}$ March 1978) Commencement.” Consequently, section 1 states that: “... all land comprised in the territory of each State in the Federation are hereby vested in the Governor of that State and such land shall be held in trust and administered for the use and common benefit of all Nigerians in accordance with the provisions of this Act."

${ }^{23}$ In this context, the territories are the 36 states and the Federal Capital Territory. The trustees of the states are the governors and the federal capital territory is under the trusteeship of the Minister specially appointed for that function.
} 
under or upon any land in Nigeria or in, under or upon the territorial waters and the Exclusive Economic Zone of Nigeria shall vest in the Government of the Federation and shall be managed in such manner as may be prescribed by the National Assembly."

It is worth noting that, the word "vest" in the above constitutional provision does not implies trusteeship but sole ownership. For example, in many Islamic countries that produces crude oil and natural gas, land ownership is supposed to be created by the authority of the Holy Qur'an which allow individuals to own land and other related rights. On the contrary, Article 21, Law No. 1 of 1962 of The State of Kuwait provides as follows:

"All of the natural wealth and resources are the property of the State. The State shall preserve and properly exploit those resources, heedful of its own security and national economy requisites. ${ }^{, 24}$

In reality, state ownership of mineral resources has been on the rise for decades, according to UNCTAD ${ }^{25}$ documents, from late 1940s to 1950s, the European countries have been in the forefront of state ownership of mineral resources. For example, in 1956, Finland, took the control of Outokumpu mineral lands from private owners. In 1906, the Swedish parliament passed the law to purchase the entire LKAB mineral lands from the private owners and in 1956 the property was completed acquired. Following independence of the colonies across the developing countries, many of the former colonies started to nationalise and take control of all mineral lands from about 1960 to date.

The implication of national ownership and control of lands and, in fact, the mineral lands, is that, private property 'owners' cannot exercise their rights over minerals that are extracted from 'their' lands. This consequently defeats the common law maxim of ad coelum. The capacity of the central governments to manipulate all the political and economic facets of its territorial boundaries has been dangerously encouraged by the growing exercise of land control system. The consistent use of such rights scoop vital economic resources which otherwise would have been used by private parties for general development of many other sectors. For example, in Attorney-General of the Federation v. 36 States of Nigeria ${ }^{26}$ the federal government of Nigeria sought to declare that, it is entitled to reduce the percentage of revenue receivable by any section of the country. It was held that the reduction in revenue allocation of the Niger Delta from $13 \%$ to $10 \%$ was unconstitutional and therefore illegal. ${ }^{27}$ The case demonstrates the extent to which the central government is interfering with the residual powers of the component units of the federation and, the contentious nature of government control of crude oil lands and how it shares the revenue.

The national laws that vests all lands within a country in the government or on the monarch deprives individuals, communities and groups of the rights to property. This deprivation of the benefits of lands, is contrary to numerous international human rights laws, including Article 1(2) of the International Covenant on Civil and Political Rights (ICCPR) which provides inter alia:

"All peoples may, for their own ends, freely dispose their natural wealth and resources without prejudice to any obligations arising out of international economic co-operation, based upon the principle of mutual benefit, and international law. In no case, may a people be deprived of its own means of subsistence."

\section{The Legality of Horizontal Drilling of Mineral Resources}

Ragsdale $^{28}$ argues that, "several potential theories of liability may arise from a subsurface entry into a neighbouring oil or gas formation. These theories of liability include: Subsurface trespass; conversion; private nuisance; and negligence." He went further to emphasize that:

"In modem times, the common law tort of trespass constitutes an "intentional and

\footnotetext{
${ }^{24}$ Kuwait's Constitution of 1962, Reinstated in 1992

${ }^{25}$ UNCTAD, World Investment Report, New York and Geneva, p. 108 (2007)

${ }^{26}$ SC28/2001 (Supreme Court of Nigeria)

${ }^{27}$ In reaching the decision, the court invoked Section 162(1) of the Constitution of the Federal Republic of Nigeria 1999 which stipulates that the Federation Account is the only account where national revenues shall be kept; the section of the constitution also provide for the revenue sharing policies (Adapted from, Kingston, Kato Gogo (2014) (Unpublished) Pollution and Environmental Responsibility In Petroleum Extraction In The Niger Delta Of Nigeria: Modelling The Coase Theorem. PhD Law thesis submitted to the University of East London, England, United Kingdom, p. 63

28 Ragsdale, Terry D. Hydraulic Fracturing: The Stealthy Subsurface Trespass, 28 Tulsa L. J. 311 (1992). Available at: http://digitalcommons.law.utulsa.edu/tlr/vol28/iss3/1 accessed 10 March 2017, p. 136
} 
unprivileged use or other invasion of another person's real property."' The trespasser's action must have substantially caused or permitted the tangible invasion of another person's possessory interests in real property. In the petroleum context, a subsurface trespass may result from at least three types of subsurface entries into an offsetting reservoir: Directionally [horizontal] drilled wells; injected fluids in enhanced recovery projects; and hydraulic fracture operations. ${ }^{, 29}$

In this paper, we are concerned with horizontal drilling, as a possible aspect of the subsurface trespass. Horizontal drilling is a process of drilling of non-vertical wells. It has three core classifications namely: oilfield slant drilling; horizontal boring; and, surface-in-seam (SIS). The SIS is the most crucial aspect of the entire process in that, it involves the horizontal intersection of the vertical well target to extract the targeted minerals.

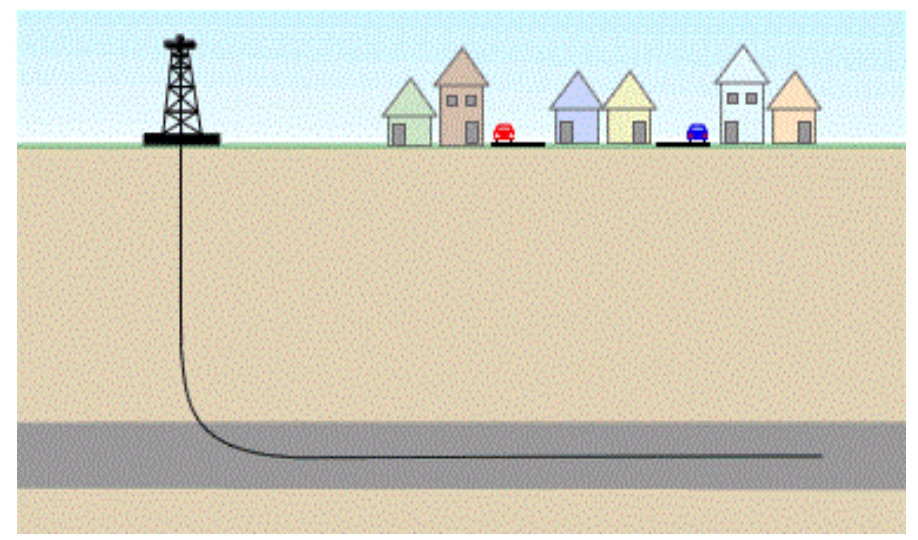

Figure 1. Example of slant (horizontal) drilling ${ }^{30}$

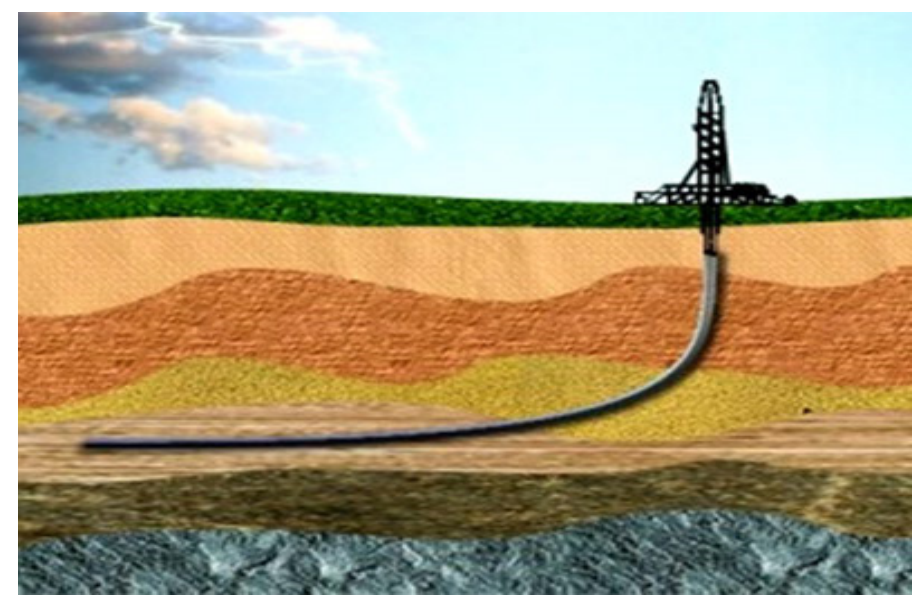

Figure 2. Further example of slant (Horizontal) drilling ${ }^{31}$

Historically, engine-drilling technology was first used in Canada and the United States, for commercial oil wells between early 1850s and late 1860s. In about 1934, John Eastman and Roman Hines invented the technique of drilling rig at a slant (horizontally) to accomplish needed purposes. This slant drilling technique incorporated the style now known as "mud motor," which involve the model known as progressive cavity positive displacement pump (PCPD). The PCPD is routinely positioned directly at the back of the drill bit together with the drill string. ${ }^{32}$ In recent years, the drilling system has been developed along with the rotary steerable systems (RSS).

\footnotetext{
${ }^{29}$ Ibid, at 137

${ }^{30}$ Source: www.geology.com accessed $10^{\text {th }}$ October 2016. Slant drilling is also known as directional or horizontal drilling. Also in Kingston, Kato Gogo Oil and Gas Laws: A Guide for International Practitioners. Germany: Lambert Academic Publishers (2017)

${ }^{31}$ Source: www.rigzone.com accessed $10^{\text {th }}$ October 2016

32 Pedigo, Tyler Directional Drilling: A Paradigm Shift In Energy Exploration And Recovery (2017); Online at: https:/tylerpedigo.com/2017/02/25/directional-drilling-a-paradigm-shift-in-energy-exploration-and-recovery/ accessed 4 March 2017
} 
The RSS enables the drilling machinists to be able to manipulate and guide the drill bit to any chosen directions during the drilling process and when the drill is actively loaded and deep beneath the earth surface.

In the extraction of liquid and gaseous minerals, horizontal drilling has been found to possess substantial benefits as compared with the traditional (vertical) drilling methods. Firstly, it enables the operators to be able to drill multiple wells from the same rig. Secondly, it removes structural constrictions with regard to the site of the drilling rig. This creates logistic convenience to the extent that, the operators do not have to keep moving equipment from one location to another. This is also good for sustaining health natural habitats without causing much harm to the environment. In essence, "resources located under small bodies of water can be extracted from the shore, and resources located under cities or populated areas can be safely extracted from a safe distance."33

The inventors of horizontal drilling may not have contemplated using the process for criminal purposes or for the violation of the rights of others. However, lawyers, particularly, the proponents of the common law doctrine of trespass, argue that, slant drilling violates the property rights of others. For example, in Figure 1 above, it could be seen that, the rig drill tilts far from the drill site and into a residential area which may or may not be the property of the drilling firm. These circumstances, call to question the validity of horizontal drilling. The contemporary response to this apprehension is that: "The trespass response is based upon the extension of surface property lines to define the rights to sub-surface geologic structures. The basic flaw with this analysis is that the oil and gas reservoir is an interconnected geologic system that cannot be divided into segregated parts. Instead, each owner has collective as well as individual rights in the reservoir." ${ }^{34}$ There are circumstances where horizontal drilling into another's property is actionable in tort of trespass and conversion. In Kelly v. Ohio Oil, ${ }^{35}$ the plaintiff sought injunction and damages against the defendant for drilling of oil and extracting crude oil along his land. It was held that:

- Oil does not automatically become property until it is extracted from the land, before it can be claimed as the personal property of the person that extracted it.

- It is irrelevant where the oil came from originally so long as it was naturally drained into the owners well.

- Kelly could have protected his rights to property by drilling his own oil wells along the property lines. ${ }^{36}$

\section{The Legality of Cross-Border Horizontal Drilling}

On the face of it, trespass to property is actionable in tort. Where the tort of trespass is proved, and where the act constituting the trespass is horizontal drilling, then it can be construed as an unlawful act. However, trespass action cannot be sustained without proven evidence of the existence of property rights. This being the legal norm, within in-country horizontal drilling, trespass will only be actionable where the mineral ownership of the land is different from the surface owner, and where there is no express or implied consent thereof. As earlier stated, in countries such as the United States, where private ownership of mineral land is allowed by law, trespass action is possible. For example, Vandenberg ${ }^{37}$ explains that: “ [The US state of ] Texas law has only recently codified in precedential decisions a reasonable formula for production allocations for horizontal, including fracked, wells. The ancient regime of the Rule of Capture does not generally apply, because of the nature of the geologic deposits and the new technology. This reasonable formula is applicable in the international arena for cross-border deposits and production blocks. Other national law and international treaties provide scant guidance in these matters and governments, national oil companies and international oil companies should review this formula to aid in negotiations for fair and equitable allocations that should preclude unnecessary disputes and litigation."’38 On the other hand, in countries, for example, Nigeria and Kuwait where all minerals are owned by the state, tort action for trespass is almost impossible. Hence, horizontal drilling is not illegal to the extent of the oil prospecting and production contracts.

In circumstances where horizontal drilling is conducted across national border into another sovereign state, this

\footnotetext{
${ }^{33}$ ibid, p. 5

${ }^{34}$ An excellent argument adapted from Pierce, David E. (2014) Resolving Intra-Reservoir Horizontal Drilling Conflicts Using a Reservoir Community Analysis. North Dakota Law Review, Vol. 90, No. 2, 2014. Available at SSRN: https://ssrn.com/abstract=2639875, at. p. 1

3549 N.E. 399 (Ohio 1897)

${ }^{36}$ Kingston, Kato Gogo (2017) ibid, p. 40

${ }^{37}$ Vandenberg, David (2015) Horizontal-well production allocation in the international context: a reasonable formula for allocation derived from Texas law. Journal of World Energy Law and Business 8 (3): 216-231

${ }^{38}$ Ibid, p. 220
} 
will be construed as a violation of territorial integrity hence, illegal. Nonetheless, where the drilling shaft merely captures the migrating minerals within the straddle reservoir, the act will not be illegal.

\section{The Possible Benefits of Intra-Field Horizontal Drilling}

Horizontal Directional Drilling (HDD) is, arguably, the most lucrative technique of extracting minerals. It could be used as a means of avoiding trouble prone areas. For example, where there are multiple oil wells situated in a cluster within localities the HDD process could be used to pool the liquid and gaseous minerals to a central safe platform. Many countries, particularly Nigeria may be able to take advantage of the horizontal drilling techniques to reduce production and extraction costs. In Nigeria, the technique could significantly reduce the interruption of crude oil production activities by the resistant groups that are consistently disrupting the oil facilities in the Niger Delta. In the past two decades, the residents of the Niger Delta of Nigeria have been resisting what they call 'government theft of private tribes' natural resources. The resistance has degenerated widely across the region leading to substantial disruption to crude oil production. Also, the environmental impact of multiple oil fields within few kilometres can be minimised through unified platform.

\section{Conclusion}

From the foregoing treatise, we are of the firm view that land ownership is the key to decision making regarding surface and sub-surface minerals. The interface between the law of property and the tort of trespass is best illustrated when there is a clear demarcation between subsurface and surface rights and between the implied and express prospecting license. Whether land is privately owned or under the control of the sovereign authority or government, it is crucial to note that horizontal drilling technology will always be used by the oil corporations. However, the issues that will often be a subject of contest is the extent to which the operators of oil facilities will be transparent and whether the property rights of neighbouring land owners will not be violated. To minimise unlawful use of horizontal drilling within national geographic areas, some scholars, ${ }^{39}$ have suggested the adoption of correlative rights. It is, arguably, the best and sustainable framework for the preservation of several owners' rights in the straddle and non-straddle reservoirs. Although, cross-border horizontal drilling may have to go through a more complex inter-country negotiated agreements such as joint development agreement or cross-border unitisation contracts it could be illegally used to steal crude oil and allied products. Horizontal drilling is, therefore a very valuable but controversial mode of crude oil operation.

\section{Copyrights}

Copyright for this article is retained by the author(s), with first publication rights granted to the journal.

This is an open-access article distributed under the terms and conditions of the Creative Commons Attribution license (http://creativecommons.org/licenses/by/4.0/).

\footnotetext{
${ }^{39}$ For example, Pierce, David E. (2014) Resolving Intra-Reservoir Horizontal Drilling Conflicts Using a Reservoir Community Analysis. North Dakota Law Review, Vol. 90, No. 2 Available at SSRN: https://ssrn.com/abstract=2639875, at. p. 1 Retrieved 20 July 2017
} 